Artikel Penelitian

\title{
Kajian Waktu dan Suhu Pelayuan Daun Alpukat dalam Upaya Pemanfaatannya sebagai Teh Herbal
}

\section{Study of Withering Time and Temperature Avocado Leafin the Useas Herbs Tea}

I Wayan Rai Widarta*, I Dewa Gede Mayun Permana, Anak Agung Istri Sri Wiadnyani

Program Studi IImu dan Teknologi Pangan, Fakultas Teknologi Pertanian, Universitas Udayana, Badung

*Korespondensi dengan penulis (rai_widarta@yahoo.com)

Artikel ini dikirim pada tanggal 01 Januari 2018 dan dinyatakan diterima tanggal 24 Mei 2018. Artikel ini juga dipublikasi secara online melalui www.https://ejournal2.undip.ac.id/index.php/jatp. Hak cipta dilindungi undang-undang. Dilarang diperbanyak untuk tujuan komersial.

Diproduksi oleh Indonesian Food Technologists ${ }_{(}(2018$

\section{Abstrak}

Daun Alpukat mengandung komponen bioaktif yang tinggi sehingga dapat dimanfaatkan sebagai pangan fungsional seperti teh herbal. Tujuan dari penelitian ini adalah mendapatkan suhu dan waktu pelayuan daun alpukat yang tepat sehingga menghasilkan teh herbal dengan karakteristik sensoris terbaik serta komponen bioaktif dan aktivitas antioksidan yang tinggi. Pelayuan dilakukan dengan cara pengukusan pada suhu 80,90 , dan $100^{\circ} \mathrm{C}$ selama 1,3 dan 5 menit. Karakteristik teh yang diamati meliputi kadar total tanin, kadar total fenol, total flavonoid dan aktivitas antioksidan serta evaluasi sensorisnya. Hasil penelitian menunjukkan bahwa suhu dan waktu pelayuan yang terbaik diperoleh pada suhu $90^{\circ} \mathrm{C}$ selama 5 menit dengan karakteristik teh herbal daun alpukat yang dihasilkan yaitu total fenolik 296,48 mg/g ekstrak, total flavonoid $644 \mathrm{mg} / \mathrm{g}$ ekstrak, total tanin 315,14 mg/g ekstrak, warna seduhan teh coklat kekuningan, rasa agak tidak pahit dan aroma agak khas daun alpukat serta dengan penerimaan keseluruhan agak suka. Sementara itu, nilai IC50 baik yang diukur dengan metode DPPH maupun reducing power masing-masing adalah $527,93 \mathrm{mg} / \mathrm{L}$ dan $78,95 \mathrm{mg} / \mathrm{L}$. Kesimpulannya, suhu dan waktu pelayuan daun alpukat berpengaruh terhadap komponen bioaktif dan aktivitas antioksidan yang terkandung pada teh herbal yang dihasilkan.

Kata kunci: antioksidan, daun alpukat, teh herbal, karakteristik sensoris

\section{Abstract}

Avocado leaves contain high bioactive components that can be used as functional food such as herbal tea. The purpose of this research was to obtain the appropriate withering time and temperature to produce herbs tea with the best sensory characteristics, high bioactive compounds and antioxidant activity. The withering was carried out by steaming at 80,90 , and $100^{\circ} \mathrm{C}$ for 1,3 and 5 minutes. The observation of herb tea characteristics were total tannin content, total phenolic content, total flavonoids, antioxidant activity, and sensory evaluation. The results showed that the best temperature and whithering time were obtained at $90^{\circ} \mathrm{C}$ for 5 minutes with the herb tea characteristic of total phenolic was $296.48 \mathrm{mg} / \mathrm{g}$ extract, total flavonoid was $644 \mathrm{mg} / \mathrm{g}$ extract, total tannin was $315.14 \mathrm{mg} / \mathrm{g}$ extract, yellowish brown tea color, slightly bitter taste and a rather typical scent of avocado leaf as well as with overall acceptance rather like. Whereas, IC50 value measured using DPPH and reducing power were $527.93 \mathrm{mg} / \mathrm{L}$ and $78.95 \mathrm{mg} / \mathrm{L}$. As conclusion, temperature and whithering time effected to the bioactive component and antioxidant activity of herb tea.

Keyword : antioxidant, avocado leaf, herb tea, sensoris caracteristics

\section{Pendahuluan}

Tanaman Alpukat merupakan tanaman yang tumbuh di daerah tropis dan subtropis, sehingga tanaman ini sangat mudah ditemui di Indonesia. Daun alpukat telah diketahui sebagai sumber antioksidan serta mempunyai manfaat yang sangat baik bagi kesehatan khususnya untuk penyakit-penyakit kardiovaskuler seperti antihipertensi (Tahla et al., 2011), obat hiperlipidemia (Kolawole et al. 2012), dan antidiabetes (Marrero-Faz et al., 2014; Antia et al. 2005). Manfaat daun alpukat dalam mengatasi berbagai penyakit kardiovaskuler tersebut diperoleh dari komponen bioaktifnya, salah satunya adalah senyawa flavonoid. Mink et al. (2007) melaporkan bahwa konsumsi beberapa produk pangan yang kaya akan kadar flavonoid dapat menurunkan resiko jantung koroner dan kematian akibat penyakit kardiovaskuler.

Hasil penelitian terdahulu yang telah dilakukan menunjukkan bahwa daun alpukat memiliki kadar komponen bioaktif dan aktivitas antioksidan yang tinggi. Diantaranya total total fenol, total flavonoid dan total tanin masing-masing sebesar adalah $23,28 \mathrm{mg} / \mathrm{g}$ bahan, $93,97 \mathrm{mg} / \mathrm{g}$ bahan, $9,47 \mathrm{mg} / \mathrm{g}$ bahan. Sementara itu, aktivitas antioksidan yang dilihat dari nilai $\mathrm{IC}_{50}$ dengan metode DPPH, reducing power, dan chelating activity masing-masing adalah $1870 \mathrm{mg} / \mathrm{L}, 85,24 \mathrm{mg} / \mathrm{L}$, dan 1180 mg/L (Widarta dan Arnata 2017). Berdasarkan komposisi komponen bioaktif dan aktivitas antioksidan yang dikandungnya menunjukkan bahwa daun alpukat memiliki potensi besar untuk dimanfaatkan sebagai minuman fungsional.

Daun alpukat selama ini sangat jarang dimanfaatkan oleh masyarakat, meskipun ada sebagian kecil masyarakat yang telah mengolahnya menjadi minuman. Pengolahannya sangat sederhana hanya dengan merebus daun alpukat kemudian air rebusan tersebut digunakan untuk minuman. Oleh karena itu, perlu dilakukan pengkajian secara ilmiah pemanfaatan 
daun alpukat ini menjadi minuman fungsional seperti teh herbal.

Teh herbal pada dasarnya campuran herbal yang terbuat dari daun, biji dan/atau akar berbagai tanaman. Teh herbal tidak seperti teh pada umumnya yang menggunakan daun Camellia sinensis, dimana teh herbal tidak mengandung cafein (Ravikumar, 2014). Proses pengolahan teh hijau meliputi pemilihan bahan baku, pelayuan, penggilingan, dan pengeringan. Teh herbal daun alpukat yang dihasilkan diharapkan dapat dimanfaatkan sebagai minuman fungsional yang bermanfaat bagi kesehatan khususnya untuk terapi berbagai penyakit kardiovaskuler.

Faktor penting yang mempengaruhi produk teh yang dihasilkan adalah pelayuan. Pada pengolahan teh hijau, proses pelayuan ini juga bertujuan untuk menginaktifkan enzim khususnya polifenoloksidase sehingga akan menghambat terjadinya proses fermentasi (Turkmen et al., 2009). Suhu dan waktu pelayuan yang tepat akan menghasilkan teh herbal dengan karakteristik kimia dan sensoris yang baik. Untuk itu, penelitian ini bertujuan untuk melakukan pemilihan metode pelayuan yang tepat sehingga menghasilkan karakteristik teh herbaldaun alpukat yang terbaik.

\section{Materi dan Metode}

Materi

Bahan-bahan yang digunakan dalam penelitian ini adalah daun alpukat yang diperoleh dari kebun di Denpasar, 1,1-Diphenyl-2-picrylhydrazyl (DPPH), reagen Folin-Ciocalteu, etanol, akuades, metanol, $\mathrm{NaOH}$, sodium karbonat, standar tanic acid, reagen Follin Denis, standar asam galat, buffer posfat, $\mathrm{NaNO}_{2}$, $\mathrm{AlCl}_{3}$, potasium ferisianida, trichloroacetic acid, $\mathrm{FeCl}_{3}$, dan standar kuersetin. Alat-alat yang dipergunakan dalam penelitian ini adalah sonicator (Elma $\mathrm{S} 450 \mathrm{H})$, oven, spektrofotometer (Genesys 10S UV-Vis), rotary evaporator vakum(IKA RV 10 basic), timbangan analitik (Shimadzu ATY224), Waterbath (J.P. Selecta), kertas Whatman No. 1, dan alat-alat gelas.

\section{Metode}

Penelitian dilaksanakan selama periode JuniSeptember 2017. Penelitian meliputi proses pembuatan teh herbal daun alpukat, ekstraksi komponen bioaktif teh herbal daun alpukat, pengujian sensoris teh herbal daun alpukat dan karakterisasi produk terbaik yang dihasilkan.

\section{Persiapan sampel}

Pembuatan teh herbal daun alpukat dimulai dari persiapan bahan berupa pencucian dan penirisan daun alpukat, pelayuan dengan pengukusan pada suhu 80 , 90, dan $100^{\circ} \mathrm{C}$ selama 1,3 , dan 5 menit (sesuai perlakuan), pendinginan, pengeringan pada suhu $90^{\circ} \mathrm{C}$ selama 25 menit, penghilangan batang dan tulang daun, serta penggilingan (Topuz et al., 2014). Selanjutnya teh herbal daun alpukat kering dihaluskan dengan menggunakan blender kemudian diayak dengan ayakan 40 mesh. Hasil yang diperoleh adalah teh herbal daun alpukat yang sebagian digunakan untuk proses ekstraksi dan sisanya dimasukan ke dalam kantong teh celup untuk uji sensoris. Tiap kantong diisi dengan $2 \mathrm{~g}$ bubuk teh herbal daun alpukat.

\section{Ekstraksi teh herbal daun alpukat}

Sebanyak $7 \mathrm{~g}$ teh herbal daun alpukat dilarutkan dengan $70 \mathrm{ml}$ pelarut etanol $80 \%$. Perbandingan bahan dengan pelarut adalah 1:10 (b/v) kemudian di tempatkan dalam sonikator selama 30 menit pada suhu kamar dengan frekuensi $37 \mathrm{kHz}$. Selanjutnya disaring dengan kertas saring whatman no 1. Filtrat yang diperoleh dipekatkan dalam rotari evaporator vakum pada suhu $30^{\circ} \mathrm{C}$ sehingga diperoleh ekstrak kasar (Widarta dan Arnata, 2017). Ekstrak kasar yang diperoleh selanjutnya dianalisis : kadar total flavonoid, total tanin, total fenolik dan aktivitas antioksidan (\% penghambatan radikal $\mathrm{DPPH}$ ). Indikator hasil penelitian terbaik pada tahap ini adalah ekstrak yang memiliki aktivitas antioksidan tertinggi. Hasil terbaik pada tahap ini selanjutnya diuji aktivitas antioksidannya melalui dua metode yaitu, penentuan nilai $\mathrm{IC}_{50}$ dengan metode DPPH dan reducing power.

\section{Prosedur Penentuan Total Fenolik}

Penentuan total fenolik dengan metode FolinCiocalteau (Garcia et al. 2007). Reagen Folin-Ciocalteu didilusi dengan air 1 : $9(\mathrm{v} / \mathrm{v})$. Ke dalam 1,25 $\mathrm{ml}$ reagen ini ditambahkan $50 \mu$ l sampel. Setelah itu diinkubasi selama 2 menit pada suhu ruang, kemudian ditambahkan $1 \mathrm{ml}$ sodium karbonat ( $75 \mathrm{~g} / \mathrm{L})$. Selanjutnya diinkubasi selama 15 menit pada suhu $50^{\circ} \mathrm{C}$ dan didinginkan dengan cepat dalam wadah yang berisi air es. Absorbansi dibaca pada panjang gelombang $760 \mathrm{~nm}$ dalam 15 menit. Hasil pembacaan dibandingkan dengan kurva standar menggunakan asam galat.

\section{Prosedur Penentuan Total Flavonoid}

Sebanyak $1 \mathrm{ml}$ sampel dicampur dengan $4 \mathrm{ml}$ akuades dan $0,3 \mathrm{ml}$ larutan $\mathrm{NaNO}_{2}(5 \%)$. Setelah 5 menit, ditambahkan $0,3 \mathrm{ml}$ larutan $\mathrm{AlCl}_{3} \quad(10 \%)$, kemudian divortex dan dbiarkan selama 6 menit. Selanjutnya ditambahkan $2 \mathrm{ml}$ larutan $\mathrm{NaOH}$ (1 M) dan 2,4 $\mathrm{ml}$ akuades, lalu langsung diuji dengan spektrofotometer. Absorbansi campuran diukur pada panjang gelombang $510 \mathrm{~nm}$. Kurva standar kuersetin disiapkan (0-12 $\mathrm{mg} / \mathrm{ml})$. Konsentrasi flavonoid dalam sampel uji dihitung dari standar kalibrasi dan dinyatakan sebagai ekuivalen kuersetin dalam $\mathrm{mg} / \mathrm{g}$ sampel (Josipovic et al., 2016).

\section{Prosedur penentuan Total Tanin}

Ekstrak sebanyak 0,1 ml dicampurkan dengan 0,5 $\mathrm{ml}$ reagen Folin Denis dan $1 \mathrm{ml}$ larutan $\mathrm{Na}_{2} \mathrm{CO}_{3}(0,5 \%$ $\mathrm{b} / \mathrm{v}$ ) dan diencerkan hingga volumenya $10 \mathrm{ml}$ dengan menggunakan akuades. Absorbansi diukur pada panjang gelombang $755 \mathrm{~nm}$ dalam 30 menit. Total tanin pada ekstrak diekspresikan sebagai ekuivalen terhadap asam tanat (Rajan et al., 2011).

Penentuan penghambatan radikal $\mathrm{DPPH}$ dan $\mathrm{IC}_{50}$ Sebanyak $3 \mathrm{ml}$ DPPH $(0,004 \%$ b/v dalam metanol) dilarutkan dengan $100 \mu \mathrm{l}$ ekstrak daun alpukat 
(konsentrasi 1\%) dalam tabung reaksi. Larutan dishaker dan diinkubasi selama 30 menit dalam gelap dan suhu ruang. Absorbansi dibaca pada panjang gelombang 517 $\mathrm{nm}$ terhadap kontrol (sebagai 100\%) menggunakan spektrofotometer. Metanol digunakan sebagai blanko. Persentase kemampuan menangkap radikal bebas (aktivitas antioksidan) dihitung dengan rumus absorbansi kontrol dikurangi dengan absorbansi sampel lalu dibagi dengan absorbansi kontrol dikalikan seratus. Absorbansi kontrol adalah absorbansi DPPH ditambahkan dengan metanol. Absorbansi sampel adalah absorbansi DPPH dengan ekstrak. Selanjutnya hasil perhitungan dimasukkan ke dalam persamaan regresi $Y=a X+b$. Konsentrasi ekstrak (100-2000 mg/L) sebagai absis (sumbu $X$ ) dan nilai \% inhibisi (aktivitas antioksidan) sebagai ordinatnya (sumbu $Y$ ). Nilai $I_{50}$ dari perhitungan pada saat $\%$ inhibisi sebesar 50\% (Khan et al. 2012).

\section{Prosedur penentuan Reducing Power}

Sebanyak $1 \mathrm{ml}$ larutan ekstrak dengan konsentrasi $(20,40,60,80$, dan $100 \mathrm{mg} / \mathrm{L})$ ditambahkan dengan $2,5 \mathrm{ml}$ buffer fosfat $(0,2 \mathrm{M}, \mathrm{pH} 6,6)$ dan $2,5 \mathrm{ml}$ potasium ferisianida $\mathrm{K}_{3} \mathrm{Fe}(\mathrm{CN})_{6}(10 \mathrm{~g} / \mathrm{L})$, kemudian dikocok dan diinkubasi pada suhu $50^{\circ} \mathrm{C}$ selama 20 menit. Selanjutnya ditambahkan $2,5 \mathrm{ml}$ trichloroacetic acid $(100 \mathrm{~g} / \mathrm{L})$ kemudian disentrifugasi pada kecepatan $3000 \mathrm{rpm}$ selama 10 menit. Sebanyak $2,5 \mathrm{ml}$ supernatan ditambahkan $2,5 \mathrm{ml}$ akuades dan $0,5 \mathrm{ml} \mathrm{FeCl}_{3}(1 \mathrm{~g} / \mathrm{L})$. Absorbansi diukur pada panjang gelombang $700 \mathrm{~nm}$ menggunakan spektrofotometer UV-Vis (Rajan et al., 2011). Rumus untuk menentukan \% reducing power adalah absorbansi sampel dibagi dengan absorbansi blanko lalu dikurangi dengan satu yang kemudian dikalikan seratus.

\section{Prosedur pengujian sensoris}

Sebanyak 1 kantong contoh yang mengandung 2 $\mathrm{g}$ bubuk teh herbal daun alpukat dimasukkan ke dalam gelas piala $300 \mathrm{ml}$, kemudian ditambahkan air mendidih sebanyak $200 \mathrm{ml}$. Dibiarkan selama 5 menit sambil kantong digerakkan naik turun dalam air. Selanjutnya kantong dikeluarkan dan dibiarkan sampai suhu kamar (SNI 3753:2014). Uji karakterstik sensoris menggunakan uji skoring (skala 1 sampai 5) dan uji hedonik (skala 1 sampai 5), dengan skala 1 sebagai yang "sangat lemah atau sangat tidak disukai" untuk masing-masing parameternya (Lee et al. 2013). Parameter pengujian air seduhan teh herbal meliputi warna, aroma, rasa, serta penerimaan keseluruhan.

\section{Analisis Statistik}

Data yang diperoleh dianalisis keragamannya dan apabila perlakuan berpengaruh nyata maka akan dilanjutkan dengan uji Duncan pada tingkat signifikansi $a=0,05$.

\section{Hasil dan Pembahasan}

Total fenolik

Hasil analisis keragaman menunjukkan bahwa interaksi antara suhu dan waktu pelayuan daun alpukat berpengaruh sangat nyata terhadap total fenolik ekstrak bubuk teh herbal daun alpukat yang dihasilkan. Analisis total fenolik (Figur 1) menunjukkan bahwa kadar total fenolik tertinggi pada ekstrak bubuk teh herbal daun alpukat diperoleh pada suhu pelayuan $90^{\circ} \mathrm{C}$ selama 3 menit yaitu $296,48 \mathrm{mg} / \mathrm{g}$ ekstrak yang tidak berbeda nyata dengan suhu pelayuan $80^{\circ} \mathrm{C}$ selama 3 menit, sedangkan kadar total fenolik terendah diperoleh pada perlakuan suhu pelayuan $90^{\circ} \mathrm{C}$ selama 1 menit yaitu $167,40 \mathrm{mg} / \mathrm{g}$ ekstrak yang tidak berbeda nyata dengan suhu pelayuan $100^{\circ} \mathrm{C}$ selama $1-5$ menit dan suhu $100^{\circ} \mathrm{C}$ selama 1 menit. Kadar total fenolik tertinggi yang ditemukan pada teh herbal daun alpukat lebih tinggi dari ekstrak Micromeria hedgei dan M. persica yaitu masingmasing 263,5 dan 256,3 mg/g ekstrak (Sonboli, 2015).

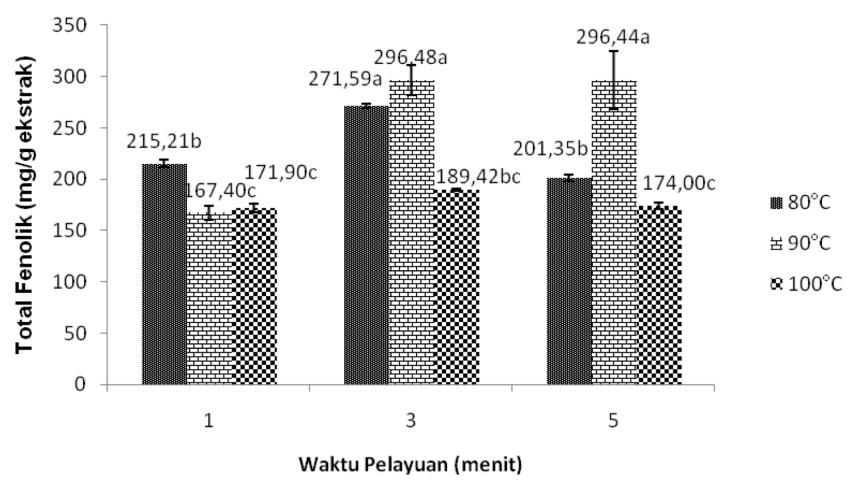

Figur 1. Hubungan antara suhu dan waktu pelayuan terhadap total fenolik ekstrak bubuk teh herbal daun alpukat. Keterangan: huruf yang berbeda dibelakang nilai rata-rata menunjukkan adanya perbedaan yang signifikan $(p \leq 0,05)$

Hasil penelitian menunjukan bahwa kombinasi antara suhu dan waktu yang paling optimum untuk menginaktifkan enzim polifenolase serta mempertahankan kandungan senyawa fenolik pada daun alpukat adalah $90^{\circ} \mathrm{C}$ selama 3-5 menit. Suhu yang lebih tinggi seperti $100^{\circ} \mathrm{C}$ akan mengakibatkan penurunan kadar total fenolik sementara itu suhu yang lebih rendah yaitu $80^{\circ} \mathrm{C}$ belum optimal untuk menginaktifkan enzim polifenolase sehingga kadar total fenol yang dihasilkan lebih rendah. Beberapa peneliti telah melaporkan terjadinya degradasi fitokimia akibat perlakuan termal seperti brokoli yang direbus selama 5 menit mengalami penurunan total fenolik sebesar $72 \%$ dan penurunan aktivitas antioksidan sebesar $65 \%$ (Zainol et al., 2009).

Steaming atau pengukusan bertujuan untuk inaktivasi enzim khususnya polifenoloksidase yang merupakan kunci dalam pengolahan teh hijau. Dalam teh, inaktivasi polifenoloksidase menghambat oksidasi katekin untuk membentuk teaflavin dan tearubigin (Turkmen et al. 2009). Polifenoloksidase bukan merupakan enzim yang sangat stabil terhadap panas. Polifenoloksidase stabil pada suhu $40^{\circ} \mathrm{C}$ dan akan terdenaturasi pada suhu yang lebih tinggi dengan waktu yang semakin lama. Hal ini disebabkan oleh perubahan struktur tersier pada suhu tinggi (Zhang dan Shao, 2015). Stabilitas senyawa polifenol sangat dipengaruhi oleh suhu terutama suhu diatas $50^{\circ} \mathrm{C}$. Pada suhu 
pemanasan ekstrak buah Cornelian cherry pada suhu 50 dan $75^{\circ} \mathrm{C}$, terjadi penurunan yang singnifikan terhadap total fenolik. Penurunan total fenolik pada suhu tinggi disebabkan oleh oksidasi senyawa polifenol. Laju oksidasinya meningkat sesuai dengan peningkatan suhu (Moldovan et al., 2016).

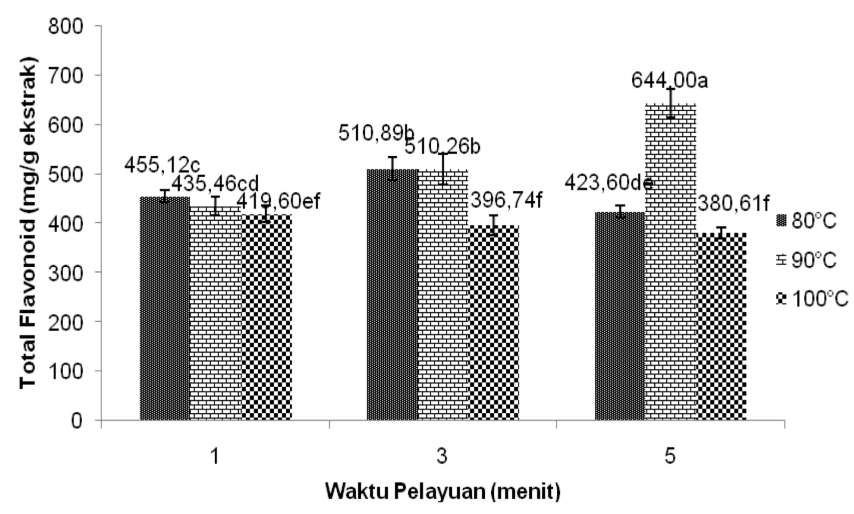

Figur 2. Hubungan antara suhu dan waktu pelayuan terhadap total flavonoid ekstrak bubuk teh herbal daun alpukat. Keterangan : huruf yang berbeda dibelakang nilai rata-rata menunjukkan adanya perbedaan yang signifikan $(p \leq 0,05)$

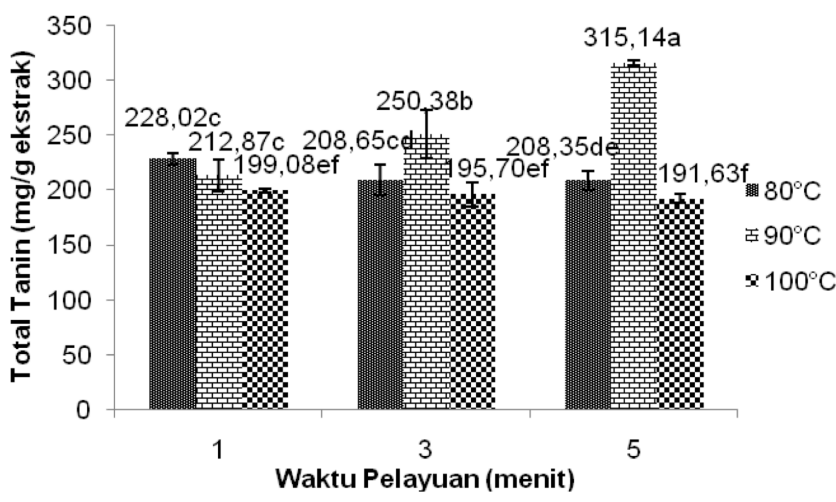

Figur 3. Hubungan antara suhu dan waktu pelayuan terhadap total tanin ekstrak bubuk teh herbal daun alpukat. Keterangan: huruf yang berbeda dibelakang nilai rata-rata menunjukkan adanya perbedaan yang signifikan $(p \leq 0,05)$

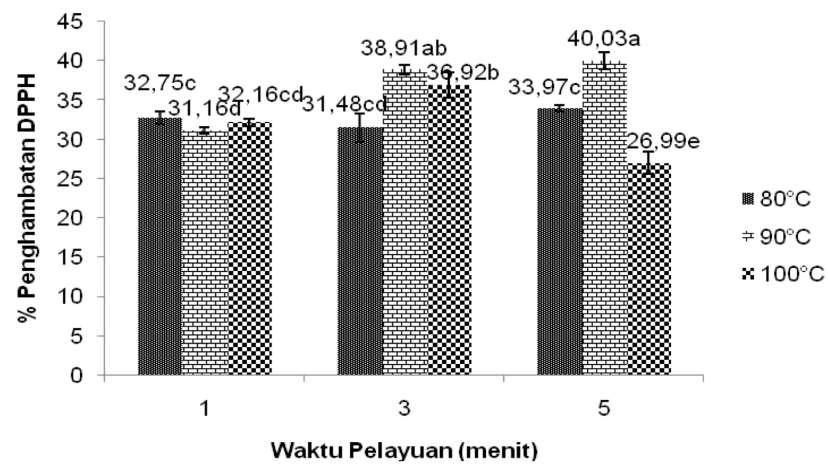

Figur 4. Hubungan antara suhu dan waktu pelayuan terhadap \% penghambatan radikal DPPH ekstrak bubuk teh herbal daun alpukat. Keterangan : huruf yang berbeda dibelakang nilai rata-rata menunjukkan adanya perbedaan yang signifikan $(p \leq 0,05)$
Total Flavonoid

Hasil analisis keragaman menunjukkan bahwa interaksi antara suhu dan waktu pelayuan daun alpukat berpengaruh sangat nyata terhadap total flavonoid ekstrak bubuk teh herbal daun alpukat yang dihasilkan $(P<0,01)$. Nilai rata-rata total flavonoid yang dihasilkan dapat dilihat pada Figur 2.

Hasil penelitian menunjukkan bahwa kadar total flavonoid tertinggi pada ekstrak bubuk teh herbal daun alpukat diperoleh pada suhu pelayuan $90^{\circ} \mathrm{C}$ selama 5 menit yaitu $644,00 \mathrm{mg} / \mathrm{g}$ ekstrak, sedangkan kadar total flavonoid terendah diperoleh pada perlakuan suhu pelayuan $100^{\circ} \mathrm{C}$ selama 5 menit yaitu $380,61 \mathrm{mg} / \mathrm{g}$ ekstrak yang tidak berbeda nyata dengan waktu pelayuan 1 dan 3 menit pada suhu yang sama. Hal ini menunjukkan bahwa kombinasi antara suhu dan waktu yang paling optimum untuk menginaktifkan enzim polifenoloksidase serta mempertahankan kandungan total flavonoid pada daun alpukat adalah $90^{\circ} \mathrm{C}$ selama 5 menit. Suhu yang lebih tinggi seperti $100^{\circ} \mathrm{C}$ akan mengakibatkan penurunan kadar total flavonoid sementara itu suhu yang lebih rendah yaitu $80^{\circ} \mathrm{C}$ belum optimal untuk menginaktifkan enzim polifenolase sehingga kadar total flavonoid yang dihasilkan lebih rendah. Polifenoloksidase bukan merupakan enzim yang sangat stabil terhadap panas. Pemanasan pada suhu $40^{\circ} \mathrm{C}$ selama 10 menit dapat mempertahankan $65 \%$ aktivitasnya. Polifenoloksidase dapat terdenaturasi sebagian pada kisaran suhu $50-70^{\circ} \mathrm{C}$. Semakin tinggi suhu dan semakin lama waktu pemanasan maka aktivitasnya akan semakin menurun. Hal ini disebabkan oleh perubahan struktur tersier pada suhu tinggi (Zhang and Shao, 2015).

Penurunan makromolekul seperti flavonoid selama pemanasan dipengaruhi oleh suhu dan waktu yang digunakan. Pengolahan dengan pemanasan basah dapat mempengaruhi senyawa fitokimia dan integritas struktur sel yang mengakibatkan migrasi komponen sehingga menyebabkan kerugian akibat kebocoran atau kerusakan melalui berbagai reaksi kimia yang melibatkan enzim, cahaya dan oksigen (Zainol et al., 2009). Kadar total flavonoid pada ekstrak bubuk teh herbal daun alpukat lebih tinggi dari total flavonoid ekstrak metanol buah merah (Pandanus conoideus Lam) yaitu 260,03 mg/g ekstrak, namun lebih rendah dari ekstrak buah merah dengan pelarut etil asetat yaitu $697,12 \mathrm{mg} / \mathrm{g}$ ekstrak (Rohman et al. 2010).

\section{Total Tanin}

Hasil analisis keragaman menunjukkan bahwa interaksi antara suhu dan waktu pelayuan daun alpukat berpengaruh sangat nyata terhadap total tanin ekstrak bubuk teh herbal daun alpukat yang dihasilkan $(P<0,01)$. Nilai rata-rata total tanin yang dihasilkan dapat dilihat pada Figur 3.

Hasil penelitian menunjukkan bahwa kadar total tanin tertinggi pada ekstrak bubuk teh herbal daun alpukat diperoleh pada suhu pelayuan $90^{\circ} \mathrm{C}$ selama 5 menit yaitu $315,14 \mathrm{mg} / \mathrm{g}$ ekstrak, sedangkan kadar total tanin terendah diperoleh pada perlakuan suhu pelayuan $90^{\circ} \mathrm{C}$ selama 1 menit yaitu $191,63 \mathrm{mg} / \mathrm{g}$ ekstrak yang 
Tabel 1. Hasil uji sensoris air seduhan bubuk teh herbal daun alpukat

\begin{tabular}{|c|c|c|c|c|c|c|c|c|}
\hline \multirow[t]{3}{*}{ Suhu } & \multirow{3}{*}{$\begin{array}{l}\text { Waktu } \\
\text { (menit) }\end{array}$} & \multicolumn{7}{|c|}{ Nilai rata-rata } \\
\hline & & \multicolumn{2}{|c|}{ Aroma } & \multicolumn{2}{|c|}{ Rasa } & \multicolumn{2}{|c|}{ Warna } & \multirow{2}{*}{$\begin{array}{c}\text { Penerimaan } \\
\text { Keseluruhan } \\
\text { (Hedonik) }\end{array}$} \\
\hline & & Skoring & Hedonik & Skoring & Hedonik & Skoring & Hedonik & \\
\hline \multirow[t]{3}{*}{$80^{\circ} \mathrm{C}$} & 1 & $3,87 \pm 0,640$ & $4,80 \pm 1,082$ & $3,60 \pm 0,674$ & $4,93 \pm 1,060$ & $2,40 \pm 0,986$ & $5,40 \pm 1,100$ & $5,13 \pm 1,060$ \\
\hline & 3 & $4,00 \pm 0,926$ & $4,27 \pm 1,223$ & $3,00 \pm 0,910$ & $4,33 \pm 1,033$ & $2,33 \pm 0,724$ & $5,20 \pm 1,343$ & $4,93 \pm 1,033$ \\
\hline & 5 & $3,60 \pm 0,737$ & $4,33 \pm 1,589$ & $3,27 \pm 1,134$ & $4,47 \pm 1,363$ & $2,60 \pm 0,986$ & $5,20 \pm 1,642$ & $5,00 \pm 1,363$ \\
\hline \multirow[t]{3}{*}{$90^{\circ} \mathrm{C}$} & 1 & $3,60 \pm 0,828$ & $4,20 \pm 1,320$ & $3,07 \pm 1,100$ & $4,47 \pm 1,291$ & $2,40 \pm 1,056$ & $5,80 \pm 1,457$ & $4,67 \pm 1,291$ \\
\hline & 3 & $3,53 \pm 0,516$ & $4,20 \pm 1,082$ & $3,13 \pm 1,187$ & $4,33 \pm 0,990$ & $1,93 \pm 0,884$ & $4,80 \pm 1,234$ & $4,47 \pm 0,990$ \\
\hline & 5 & $3,93 \pm 0,704$ & $4,60 \pm 1,454$ & $3,27 \pm 1,280$ & $4,67 \pm 1,000$ & $1,87 \pm 0,834$ & $4,80 \pm 1,496$ & $5,00 \pm 1,000$ \\
\hline \multirow[t]{3}{*}{$100^{\circ} \mathrm{C}$} & 1 & $3,87 \pm 0,743$ & $4,13 \pm 1,457$ & $3,13 \pm 1,187$ & $4,13 \pm 0,884$ & $2,73 \pm 1,033$ & $5,20 \pm 1,457$ & $4,93 \pm 0,884$ \\
\hline & 3 & $3,07 \pm 0,704$ & $4,13 \pm 1,125$ & $3,60 \pm 0,910$ & $4,27 \pm 0,968$ & $1,80 \pm 0,775$ & $4,60 \pm 1,100$ & $4,60 \pm 0,968$ \\
\hline & 5 & $3,33 \pm 0,816$ & $4,73 \pm 1,100$ & $3,60 \pm 1,121$ & $4,73 \pm 1,056$ & $1,33 \pm 0,606$ & $4,40 \pm 1,100$ & $4,60 \pm 1,056$ \\
\hline
\end{tabular}

Tabel 2. Karakteristik produk terbaik

\begin{tabular}{lll}
\hline No & Karakteristik & Nilai \\
\hline 1 & Total Fenolik & $296,44 \pm 28,6 \mathrm{mg} / \mathrm{g}$ ekstrak \\
2 & Total Flavonoid & $644,00 \pm 29,27 \mathrm{mg} / \mathrm{g}$ ekstrak \\
3 & Total Tanin & $305,37 \pm 2,10 \mathrm{mg} / \mathrm{g}$ ekstrak \\
4 & IC $_{50}$ dengan metode DPPH & $527,93 \pm 9,27 \mathrm{mg} / \mathrm{L}$ \\
5 & IC $_{50}$ dengan metode Reducing Power & $78,95 \pm 2,90 \mathrm{mg} / \mathrm{L}$ \\
6 & Kadar Abu & $7,14 \pm 0,04 \%$ \\
7 & Kadar air & $7,89 \pm 0,42 \%$ \\
8 & Uji Hedonik & Aroma $=$ agak suka \\
& & Warna $=$ agak suka \\
& & Rasa $=$ agak suka \\
9 & Uji Skoring & Penerimaan keseluruhan = agak suka \\
& & Warna $=$ coklat kekuningan \\
& & Rasa $=$ agak tidak pahit \\
\end{tabular}

tidak berbeda nyata dengan suhu pelayuan $100^{\circ} \mathrm{C}$ waktu pelayuan 3-5 menit. Hal ini menunjukkan bahwa kombinasi antara suhu dan waktu yang paling optimum untuk menginaktifkan enzim pemecah tanin serta mempertahankan kandungan total tanin pada daun alpukat adalah $90^{\circ} \mathrm{C}$ selama 5 menit. Tanin merupakan senyawa polifenol larut air. Hydrolysable tanin dapat mengalami dekomposisi dengan katalis enzim Tanase atau Tanin Asil Hidrolase. Suhu optimum untuk aktivitas Tanase adalah $40^{\circ} \mathrm{C}$ selama 1 jam. Aktivitas enzim ini mengalami penurunan seiring dengan peningkatan suhu dan waktu pemanasan (lqbal and Kapoor, 2012). Suhu yang lebih tinggi seperti $100^{\circ} \mathrm{C}$ mampu menginaktifkan enzimnamun berdampak pada penurunan kadar total tanin, sementara itu suhu yang lebih rendah yaitu $80^{\circ} \mathrm{C}$ belum optimal untuk menginaktifkan enzim polifenoloksidase sehingga kadar total tanin yang dihasilkan lebih rendah. Tanin merupakan senyawa polifenol yang rentan terhadap panas. Kadar total tanin dapat menurun seiring dengan peningkatan suhu pemanasan (Cuong et al., 2014). Total tanin pada ekstrak bubuk teh herbal daun alpukat lebih tinggi dibandingkan total tanin pada daun Psychotriadeflexa yaitu 194,67 mg/g ekstrak (Formagio et al., 2014).

\section{Penghambatan Radikal DPPH (Aktivitas Antioksidan)}

Hasil analisis keragaman menunjukkan bahwa interaksi antara suhu dan waktu pelayuan daun alpukat berpengaruh sangat nyata terhadap penghambatan radikal DPPH ekstrak bubuk teh herbal daun alpukat yang dihasilkan $(P<0,01)$. Nilai rata-rata penghambatan radikal DPPH yang dihasilkan dapat dilihat pada Figur 4. Hasil penelitian menunjukkan bahwa penghambatan radikal DPPH tertinggi pada ekstrak bubuk daun alpukat diperoleh pada suhu pelayuan $90^{\circ} \mathrm{C}$ selama 5 menit yaitu 40,03\% yang berbeda tidak nyata dengan waktu pelayuan 3 menit pada suhu yang sama yaitu $38,91 \%$, sedangkan penghambatan radikal DPPH terendah diperoleh pada perlakuan suhu pelayuan $100^{\circ} \mathrm{C}$ selama 5 menit yaitu $26,99 \%$. Persentase penghambatan radikal DPPH pada teh herbal daun alpukat lebih tinggi dibandingkan ekstrak dari akar Asparagus racemosus yaitu 30\% (Ghimire et al., 2011) dan ekstrak bayam merah yaitu 40,38\% (Ghasemzadeh et al., 2012). Beberapa peneliti telah melaporkan terjadinya degradasi fitokimia akibat perlakuan termal seperti brokoli yang direbus selama 5 menit mengalami penurunan total fenolik sebesar $72 \%$ dan penurunan aktivitas antioksidan sebesar 65\% (Zainol et al. 2009).

Penghambatan radikal DPPH sangat terkait dengan data kadar total fenolik, total flavonoid, dan total taninyang diperoleh. Semakin tinggi total fenolik, total flavonoid, dan total tanin maka penghambatan radikal DPPH-nya juga semakin meningkat, demikian pula sebaliknya. Hasil penelitian serupa juga di laporkan oleh Widarta dan Arnata (2017) yang menyatakan bahwa 
terdapat korelasi positif antara total fenolik, total flavonoid dan total tanin terhadap aktivitas antioksidan.

\section{Evaluasi Sensoris}

Hasil uji sensoris menunjukkan bahwa suhu dan waktu pelayuan berpengaruh nyata terhadap hasil uj skoring aroma dan warna namun tidak berpengaruh nyata terhadap hasil uji skoring rasa serta uji hedonik aroma, rasa, warna, dan penerimaan keseluruhan. Adapun nilai rata-rata hasil uji sensoris dapat dilihat pada Tabel 1.

Hasil uji skoring terhadap aroma air seduhan daun alpukat menunjukkan bahwa suhu $80-90^{\circ} \mathrm{C}$ menghasilkan aroma agak khas daun alpukat sedangkan suhu yang lebih tinggi seperti $100^{\circ} \mathrm{C}$ dan waktu yang lebih lama 3-5 menit mengurangi kekhasan aroma daun alpukat. Hasil uji hedonik terhadap aroma menunjukan penilaian panelis tidak berpengaruh nyata yaitu antara biasa sampai agak suka. Hasil uji skoring rasa juga menunjukan penilaian panelis yang tidak berpengaruh nyata yaitu agak tidak sepat sampai tidak sepat dan hasil uji hedoniknya menunjukkan dari biasa sampai agak suka.

Hasil uji skoring terhadap warna menunjukkan bahwa adanya pengaruh yang nyata terhadap warna air seduhan. Warna air seduhan berkisar antara kuning kecokatan hingga coklat kekuningan dengan hasil uji hedonik agak suka. Hasil uji hedonik terhadap penerimaan keseluruhan juga menunjukkan bahwa panelis memberikan penilaian agak suka terhadap produk teh herbal daun alpukat.

\section{Karakteristik Produk Terbaik}

Berdasarkan hasil pengujian secara kuantitatif total fenolik, total flavonoid, total tanin, dan penghambatan radikal DPPH serta uji sensoris terhadap bubuk teh herbal daun alpukat, dapat disimpulkan bahwa suhu pelayuan $90^{\circ} \mathrm{C}$ selama 5 menit menghasilkan total fenolik, total flavonoid, total tanin, dan penghambatan radikal DPPH tertinggi serta uji sensoris terbaik. Oleh karena itu, karakterisasi dilakukan terhadap produk yang diperoleh dari suhu dan waktu pelayuan tersebut. Adapun karakteristik produk yang dihasilkan dapat dilihat pada Tabel 2.

Nilai $\mathrm{IC}_{50}$ bubuk teh herbal daun alpukat yang diuji dengan metode DPPH sebesar 527,93 mg/L, lebih rendah dari nilai $\mathrm{IC}_{50}$ cabai hijau yaitu $575,7 \mathrm{mg} / \mathrm{L}$ dan kunyit 600,7 mg/L (Ghasemzadeh et al., 2012), sedangkan nilai $I C_{50}$ bubuk teh herbal daun alpukat yang diuji dengan metode reducing power adalah $78,95 \mathrm{mg} / \mathrm{L}$, lebih rendah dibandingkan pada ekstrak daun alpukat yaitu $85,24 \mathrm{mg} / \mathrm{L}$ (Widarta dan Arnata, 2017).Hal ini menunjukan bahwa teh herbal daun alpukat sangat berpotensi dijadikan minuman fungsional. Kadar air dan kadar abu bubuk teh herbal daun alpukat adalah 7,89\% dan $7,14 \%$. Apabila dibandingkan dengan SNI 3945:2016 tentang Teh Hijau, maka kadar air dan kadar abu bubuk teh herbal daun alpukat telah memenuhi persyaratan. Dimana, persyaratan untuk kadar air yaitu maksimal $8 \%$ sedangkan kadar abunya yaitu $4-8 \%$ sesuai dengan SNI 3945:2016.

\section{Kesimpulan}

Hasil penelitian menunjukkan bahwa suhu dan waktu pelayuan daun alpukat berpengaruh terhadap komponen bioaktif dan aktivitas antioksidan yang terkandung pada teh herbal yang dihasilkan. Suhu dan waktu terbaik adalah $90^{\circ} \mathrm{C}$ selama 5 menit dengan komposisi komponen bioaktif yang dihasilkan yaitu total fenolik 296,48 mg/g ekstrak, total flavonoid $644 \mathrm{mg} / \mathrm{g}$ ekstrak, total tanin 305,37 mg/g ekstrak. Sementara itu, nilai IC50 baik yang diukur dengan metode DPPH maupun reducing power masing-masing adalah 527,93 $\mathrm{mg} / \mathrm{L}$ dan 78,95 mg/L. Adapun karakteristik air seduhan teh herbal daun alpukat yang dihasilkan yaitu warna seduhan teh coklat kekuningan, rasa agak tidak pahit dan aroma agak khas daun alpukat serta penerimaan keseluruhan agak suka. Dengan demikian, teh herbal daun alpukat sangat berpotensi untuk dijadikan minuman fungsional.

\section{Ucapan Terimakasih}

Ucapan terimakasih disampaikan kepada Rektor Universitas Udayana melalui Ketua LPPM atas dana penelitian yang diberikan dalam bentuk Hibah Unggulan Program Studi dengan SPK Nomor: 2248/UN14.2.12.II/ PNL.01.03.00/2017

\section{Daftar Pustaka}

Antia, B.S., Okokon, J.E., Okon, P.A. 2005. Hypoglycemic activity of aqueous leaf extract of Persea americana Mill. Indian Journal Pharmacology. 37 (5): 325-326. DOI:10.4103/ 0253-7613.16858

Cuong, R.V., Ling, L.H., Quan, G.K., Tiep, T.D., Nan, X., Qing , C.X., Lin, T.L. 2014. Effect of roasting conditions on several chemical constituents of vietnam robusta coffee. Food Technology 38(2): 43-56

Formagio, A.S.N., Volobuff, C.R.F., Santiago, M., Cardoso, C.A.L., Vieira, M.D.C., Pereira, Z.V. 2014. Evaluation of antioxidant activity, total flavonoids, tannins and phenolic compounds in Psychotria leaf extracts. Antioxidants 3:745-757. DOI:10.3390/antiox3040745

Garcia, C.A., Gavino, G., Mosqueda, M.B., Hevia, P., Gavino, V.C. 2007. Correlation of tocopherol, tokotrienol, $Y$-oryzanol and total polyphenol content in rice bran with different antioxidant capacity assays. Food Chemistry 102: 12281232. DOI:10.1016/j.foodchem.2006.07.012

Ghasemzadeh, A., Azarifar, M., Soroodi, O., Jaafar, H.Z.E. 2012. Flavonoid compounds and their antioxidant activity in extract of some tropical plants. Journal of Medicinal Plants Research 6(13):2639-2643. DOI: 10.5897/JMPR11.1531

Ghimire, B.K., Seong, E.S., Kim, E.H., Ghimeray, A.K., Yu, C.Y., Ghimire, B.K., Chung, M. 2011. A comparative evaluation of the antioxidant activity of some medicinal plants popularly used in Nepal. Journal of Medicinal Plants Research 5(10):18841891 
lqbal, H., Kapoor, A. (2012). Tannin degradation efficiency of tannase produced by Trichoderma harzianum MTCC 10841 and its biochemical properties. International Journal Life Science Biotechnology and Pharma Research 1(4): 106117

Josipovic, A., Sudar, R., Sudaric, A., Jurkovic, V., Kocar, M.M., Kulundžic, A.M. 2016. Total phenolic and total flavonoid content variability of soybean genotypes in eastern Croatia. Croatatian Journal Food Science Technology 8 (2):60-65. DOI: 10.17508/CJFST.2016.8.2.04

Khan, R. A., Khan, M.R., Sahreen, S., Ahmed, M. 2012. Evaluation of phenolic contents and antioxidant activity of various solvent extracts of Sonchus asper (L.) Hill. Chemistry Central Journal 6:1-7. DOI: $10.1186 / 1752-153 X-6-12$

Kolawole O.T., Kolawole, S.O., Ayankunle, A.A., Olaniran, I.O. 2012. Methanol leaf extract of Persea americana protects rats against cholesterol-induced hyperlipidemia. British Journal Medicine \& Medical Research 2(2): 235242

Lee, J., Chambers, D., Chambers, IV.E. 2013.Sensory and instrumental flavor changes in green tea brewed multiple times. Foods 2:554-571. DOI:10.3390/foods2040554

Marrero-Faz E., Sánchez-Calero, J., Young, L., Harvey, A. 2014. Inhibitory effect of Persea americana Mill leaf aqueous extract and its fractions on PTP1B as therapeutic target for type 2 diabetes. Boletín Latinoamericano y del Caribe de Plantas Medicinales y Aromáticas 13 (2): 144 - 151

Mink P.J., Scrafford, C.G., Barraj, L.M., Harnack, L., Hong, C., Nettleton, J.A., Jacobs Jr.D.R. 2007. Flavonoid intake and cardiovascular disease mortality: a prospective study in postmenopausal women. American Journal Clinic Nutrition 85:895909. DOI: 10.1093/ajcn/85.3.895

Moldovan, B., Popa, A., David, L. 2016. Effects of storage temperature on the total phenolic content of Cornelian Cherry (Cornus mas L.) fruits extracts. Journal of Applied Botany and Food Quality 89: 208 - 211. DOI:10.5073/JABFQ.2016.089.026

Rakic, S., Maletic, R., Perunovic, M., Svrzic, G. 2004. Influence of thermal treatment on tannin content and antioxidation effect of oak acorn Quercus Cerris extract. Journal of Agricultural Sciences 49(1): 97107. UDC: $633.873: 664.8 .03$

Rajan, S., Mahalakshmi, S., Deepa, V., Sathya, K., Shajitha, S., Thirunalasundari, T. 2011. Antioxidant potentials of punica granatum fruit rind extracts. International Journal of Pharmacy and Pharmaceutical Sciences 3: 82-88

Ravikumar, C. (2014). Review on herbal teas. Journal Pharmaceutical Science \& Research 6(5): 236238

Rohman, A., Riyanto, S., Yuniarti, N., Saputra, W. R., Utami, R., Mulatsih, W. 2010. Antioxidant activity, total phenolic, and total flavaonoid of extracts and fractions of red fruit (Pandanus conoideus Lam). International Food Research Journal 17: 97-106

Sonboli, A. Biological activity of various extracts and phenolic content of Micromeria persica and $M$. hedgei. Research Journal of Pharmacognosy 2(4): 27-31

Tahla J., Priyanka, M., Akanksha, A. 2011. Hypertension and herbal plants. International Research Journal of Pharmacy 2(8): 26-30

Topuz, A., Dincer, C., Torun, M., Tontul, I., Nadeem, H.S., Haznedar, A., Özdemir, F. 2014. Physicochemical properties of turkish green tea powder: Effects of shooting period, shading, and clone. Turkish Journal of Agriculture and Forestry 38:233-241. DOI:10.3906/tar-1307-17

Turkmen N., Sari, F., Velioglu, Y.S. 2009. Factors affecting polyphenol content and composition of fresh and processed tea leaves. Akademik Gida 7(6): $29-40$

Widarta, I.W.R., Arnata I.W. 2017. Ekstraksi komponen bioaktif daun alpukat dengan bantuan ultrasonik pada berbagai jenis dan konsentrasi pelarut. Agritech 37(2): 148-157. DOI: 10.22146/ agritech.10397

Zainol, M.K.M., Hamid, A.A., Bakar, F.A., Dek, S.P. 2009. Effect of different drying methods on the degradation of selected flavonoids in Centella asiatica. International Food Research Journal 16: 531-537

Zhang, X., Shao, X. 2015. Characterisation of polyphenol oxidase and peroxidase and the role in browning of Loquat fruit. Czech Journal Food Science 33(2): 109-117. DOI: 10.17221/ 384/2014-CJFS 